\title{
Prednosti in slabosti timskega dela na daljavo
}

\author{
Tjaša Gračner* \\ Fakulteta za organizacijske študije v Novem mestu, Ulica talcev 3, \\ 8000 Novo mesto, Slovenija \\ gracner.tjasa@gmail.com
}

\begin{abstract}
Povzetek:
Raziskovalno vprašanje (RV): Katere so prednosti in slabosti timskega dela na daljavo?
\end{abstract}

Namen: Raziskati prednosti in slabosti timskega dela na daljavo ter poiskati razloge za uspešno oziroma neuspešno delo na daljavo.

Metoda: S pomočjo integrativnega pregleda literature oziroma že narejenih raziskav na tem področju ter z zbiranjem podatkov smo raziskali prednosti in slabosti timskega dela na daljavo. Za pridobitev podatkov smo uporabili kvalitativno metodo, metodo kompilacije, s katero smo povzeli rezultate drugih avtorjev na omenjeno tematiko, komparativno metodo za primerjavo prednosti in slabosti timskega dela na daljavo ter deduktivno metodo, s pomočjo katere smo sklepali iz posameznih primerov na splošno.

Rezultati: Rezultati vseh raziskav se ne razlikujejo bistveno, saj so prednosti in slabosti timskega dela na daljavo zaposlenih odvisne od podobnih parametrov: delovnika, starosti, položaja $v$ podjetju, infrastrukture, možnosti kombiniranja dela in družine.

Organizacija: Vpliv na organizacijo je močan, saj organizaciji omogoča doseg boljše produktivnosti zaposlenih, imajo lahko fleksibilen delovnik, organizacija nima velikih stroškov s fizičnimi pisarnami in $s$ stroški prevoza zaposlenih na delo. Pomembno je tudi to, da se organizacije zavedajo pomena prednosti dela na daljavo in spodbujajo $\mathrm{k}$ produktivnosti, inovativnosti ter jih vodja tudi ustrezno nagradi.

Družba: Teoretična izhodišča usmerjajo družbo k uporabi dela daljavo in sodelovanju v timu, saj lahko več ljudi skupaj veliko več naredi, izboljša, inovira. Delo na daljavo ima pozitiven učinek na zaposlene.

Originalnost: Originalnost raziskave se kaže $\mathrm{v}$ členitvi prednosti in slabosti timskega dela na daljavo. Tematika se je osredotočala na izpostavljanje prednosti timskega dela na daljavo, ki v veliki meri prispeva $\mathrm{k}$ razvoju podjetja.

Omejitve/nadaljnje raziskovanje: Za širši pogled na prednosti in slabosti timskega dela na daljavo bi bilo potrebno preučiti več literature. Za nadaljnjo raziskovanje bi morali raziskati različne stroške, ki pretijo na podjetja glede uvedbe dela na daljavo in načine za pomoč podjetjem ter zaposlenim pri delu na daljavo $\mathrm{v}$ timu.

Ključne besede: tim, timsko delo, vodenje tima, komunikacija v timu, člani tima, delo na daljavo, informacijsko-komunikacijska tehnologija.

\section{Uvod}

Nova informacijska in komunikacijska tehnologija (IKT) je revolucionirala vsakdanje delo in življenje v 21. stoletju. Ljudem omogoča, da se povežejo s svojimi prijatelji, družino in tudi s službenimi kolegi ter nadzorniki. Sedaj je potrebno ločevati med tradicionalnimi pisarniškimi prostori in delom od doma s pomočjo uporabe IKT. Dandanes pisarniško delo in širše znanje

* Korespondenčni avtor / Correspondence author 
podpira internet in ga je mogoče izvesti iz praktično katerekoli lokacije in kadarkoli. Delo od doma zaposlenim omogoča večji delovni čas, avtonomijo dela, ki vodi do večje fleksibilnosti pri delu in organizacije časa, zaposleni porabijo manj časa za vožnjo na delovno mesto in predstavlja izboljšanje ravnovesja med poklicnim in zasebnim življenjem, ter večjo produktivnost. Napredek digitalne tehnologije je privedel do širitve uporabe IKT, ki omogoča delo kadarkoli in kjerkoli. $\mathrm{V}$ tem kontekstu se delo od doma povečuje, saj organizacijo vodi do večje produktivnosti, izboljšanja delovanja in tako pomagajo zaposlenim pri prostorski ter časovni prilagodljivosti.

Tim predstavlja del življenja. »Tim je skupina posameznikov, ki delajo skupaj pri uresničevanju skupnega cilja. Za člane tima je značilno, da sodelujejo pri odločanju in si pomagajo pri uresničevanju ciljev« (Kralj, 2003, str. 16). Timske inovacije so pomemben dejavnik za celotno organizacijsko učinkovitost. Spodbujanje inovativnosti v timih je glavni izziv za vodje skupin.

$\mathrm{V}$ podjetjih se večkrat zamenjuje med skupino in timom. Skupina ne zahteva veliko energije in je za podjetja manj produktivna in pomembna. Delovanje in pojmovanje med načinom dela se razlikuje glede na organiziranost, komunikacijo, cilje, zaupanje, prenos znanja in sprejemanje odločitev. Pri sami organiziranosti je razlike med skupino in timom v tem, da je skupina administrativno organizirana in so člani med seboj neodvisni, pri timu pa je pomembno samo funkcioniranje tima. (Maddux, 1992, str. 10)

Raziskovalno vprašanje tega članka je: Katere so prednosti in slabosti timskega dela na daljavo?

Glavni namen članka je raziskati prednosti in slabosti timskega dela na daljavo, ki vplivajo na samo delo in poiskati razloge za uspešno oziroma neuspešno delo na daljavo.

\section{Teoretična izhodišča}

$\mathrm{V}$ današnjem načinu življenja je timsko delo polno hitrega in učinkovitega prilagajanja spremembam, pomemben zato, da lahko člani tima $\mathrm{z}$ različnim znanjem in raznovrstnimi idejami pripomorejo $\mathrm{k}$ rešitvi bolj kot posameznik sam. V strokovni literaturi je tim opredeljen na različne načine, nekaj opredelitev bomo v nadaljevanju navedli.

Timi so delček našega življenja. Ashmos in Nathan (2002, str. 200-201) pravita: »Timi so instrumenti, s pomočjo katerih organizacija dosega željene rezultate s tem, da članom dovoli določeno sodelovanje pri odločilnem delu, kar jih motivira pri opravljanju naloge ali skupine nalog.«

Brajša (1996 v Kobolt, 2012, str. 5) opredeljuje tim kot »živ medosebni sistem«. Po njegovem mišljenju gre za »osebo, sestavljeno iz več posameznikov«. V Slovarju slovenskega knjižnega jezika (2020) zasledimo opredelitev tima: »Tim je skupina ljudi, ki opravlja skupno delo, delovna skupina.« 
»Tim je skupina posameznikov, ki delajo skupaj pri uresničevanju skupnega cilja. Za člane tima je značilno, da sodelujejo pri odločanju in si pomagajo pri uresničevanju ciljev« (Kralj, 2003, str. 16).

Brečko (2003, str. 4) pravi: « Smisel združevanja v time ponazarja že sama angleška beseda za tim - team (Together Ever Achieve More), oziroma skupaj dosežemo več kot vsakdo sam.«

Timsko delo je način hitrega in učinkovitega prilagajanja spremembam, zato so mnenja članov tima zaželena. Pri timskem delu je to zelo pomembno, saj tim ponazarja osebe, ki opravljajo skupno delo, skupen cilj in imajo vsi člani tima posredno ali neposredno korist pri skupnem dosežku.

Krejan (2005 v Lahe \& Kaučič, 2006, str. 3) navaja prednosti in pomanjkljivosti timskega dela, ki so navedene v Tabela 1.

Tabela 1. Prednosti in slabosti timskega dela

\begin{tabular}{ll}
\hline Prednosti & Slabosti
\end{tabular}

\footnotetext{
Večja motiviranost (z delovanjem v timu člani uspešnejše zadovoljijo svoje osebne in skupne potrebe, medsebojno spodbujanje).
}

Kohezija odnosov (posamezniki tima so v tesni povezavi, razvijajo visoko stopnjo komunikacije).

Sinergijski učinki (sistematično reševanje problemov, zbiranje »zlatih idej«, učenje na podlagi izkušenj, neposreden prenos znanj, uvajanje novih pristopov reševanja problemov, enako število posameznikov je manj učinkovito, pomembna je tehnološka, stroškovna, menedžerska in psihološka sinergija).

Boljša organizacija dela ( $v$ timu se organizacija procesa razvije precej višje kot pri klasičnem konceptu organiziranja, s tem se delo obogati).

Tim običajno ustvarja večje število in različne rešitve problemov.

Večja kreativnost (strokovnjaki v timu z različnim znanjem se dopolnjujejo in ustvarjajo novo skupno znanje).

Posameznik v timu ni osamljen, deležen je podpore ostalih članov, deležen je čustvene sprejetosti in lažje najde svojo identiteto.

Osebno in skupno zadovoljstvo (skupna evalvacija doseženih ciljev in obenem kritična analiza omogočata reševanje nastajajočih težav, krepi se samozavest.
Nevarnost skupnega mišljenja.

Nevarnost prevlade posameznega člana.

Prelaganje odgovornosti na druge.

Pritiski za strinjanje.

Konkurenca med člani postaja pomembnejša od reševanja problemov.

Prekrivajoča se komunikacija.

Verovanje v čarobne učinke tima.

Delo v timu zahteva več časa in za odločitve so potrebni kompromisi.

Opomba. Prednosti in pomanjkljivosti timskega dela. Prirejeno iz »Timsko delo v očeh študentov zdravstvene nege: Kateri dejavniki vplivajo na njegovo uspešnost«, po M. Lahe in B. M. Kaučič, 2006, Obzor. zdr., 2006, 40, str. 3 . 
Navedene prednosti se kažejo v motiviranosti iz strani vodje tima, posamezniki pa so v tesni povezavi med seboj in imajo visoko stopnjo komunikacije, sistematično se rešujejo problemi, člani tima se učijo na podlagi izkušenj, prenos znanja med člani je neposreden, uvajajo se novi pristopi reševanja problemov. V timu je tudi boljša organizacija dela in tako se delo obogati, razvija se kreativnost in posameznik v timu ni osamljen, saj je deležen podpore od ostalih članov. Slabosti pa so predvsem v skupnem strinjanju, konkurenca med člani postaja pomembnejša od reševanja problemov, komunikacija je prekrivajoča, delo v timu zahteva več časa za odločitve, tako da so potrebni kompromisi.

Z razvojem informacijskih tehnologij, računalniških omrežij in interneta se je začel razvoj elektronskega izobraževanja. Za informacijsko družbo je značilno, da temelji na informacijski infrastrukturi, ki je sestavljena iz telekomunikacijskih omrežij, storitev in vsebine, ki jih telekomunikacijska omrežja ponujajo. (Potor \& Jereb, 2004, str. 1) Z uvedbo moderne informacijske in komunikacijske tehnologije znotraj delovnih procesov se spreminja organizacija pisarniškega dela, kar vpliva na potrebne prostore ter posledično na zasnovo poslovnih zgradb. Eden od glavnih argumentov za uvedbo dela na daljavo je racionalizacija delovnih mest. (Kovačič, 2005, str. 93-95)

Ključni problem preučevanja dela na daljavo je dejstvo, da obstajajo različne definicije in pojmi vsebine, ki jo ta pojem obsega (e-delo, teledelo, delo na daljavo,...). Delo na daljavo bi lahko definirali kot delo, ki se izvaja na lokacijsko od sedeža podjetja oddaljenem delovnem mestu, pri čemer običajno razdaljo med njima zbližujejo sodobne informacijskotelekomunacijske tehnologije. Je prilagodljiv način dela in vključuje kot bistveni element znanje in informacije. (Skalič et al., 2006, str. 24).

Prvi primer dela na domu izvira iz leta 1877 , ko je direktor banke v Bostonu napeljal telefonsko linijo do svojega doma z namenom, da bi lahko delal tudi doma. Teledelo se je prvič pojavilo v ZDA v obdobju naftne krize (pred 30. leti), zaradi težnje po zmanjšanju potnih stroškov. Uveljavljati so se začele nove oblike dela in delovnega procesa, ki jo opredeljuje uporaba informacijske in telekomunikacijske tehnologije. Za uspešno vzpostavitev tovrstnega dela je potrebna uporaba čim boljše telekomunikacijske tehnologije, ki omogoča stalne stike delodajalca, delojemalca in čim večjo prepričanost vodstva, da delavec ne potrebuje stalnega nadzora. (Skalič et al., 2006, str. 15)

Delo na daljavo se lahko izvaja deloma ali v celoti. Velikokrat vključuje elektronsko obdelavo podatkov in informacij, vedno pa telekomunikacije, ki omogočajo stalne stike delavca na daljavo in delodajalca (Jereb, 2000, str. 328).

Večjo produktivnost in kreativnost ponuja organizacijam ter njihovim posameznikom timsko delo, ki je zelo pomembno za boljši poslovni uspeh. Maddux (1992, str. 15) je dejal: »Pomanjkanje timskega dela na kateremkoli nivoju upravljanja (ali med nivoji) omejuje organizacijsko uspešnost in lahko neko podjetje tudi uniči.« Tim potrebuje vodjo za doseganje ciljev in vodja ima pri tem zelo pomembno vlogo. Vodja mora biti zelo dober 
organizator, ki združi tim. Ko vodja organizira tim, je lahko šele vodja kot motivator, spodbujevalec, svetovalec in pomočnik celotnem timu. Lipičnik (1998, str. 314) pravi: »Slog vodenja se nanaša na določen vzorec vedenja, ki ga uporablja vodja, ko dela z ljudmi, seveda če ga kot takšnega sprejmejo.«

Delo na daljavo delimo na (Trček, 2000, str. 88):

- Delo na daljavo doma.

- Delo na daljavo na lokacijah, ki so običajno bližje kot tradicionalna delovna okolja, ki se deli na informacijske pisarne, ki so v lasti lokalnih skupnosti v soseščini in ponujajo potrebno opremo za delo na daljavo, ki si jo delijo različni uporabniki, satelitske pisarne so krajevno ločene organizacijske enote enega samega podjetja, kjer se kraj pisarne izbere glede na prebivališča zaposlenih; organizacija pisarne je lahko enaka kot v podjetju in so zajete vse enote podjetja, lahko pa so v pisarni le določene funkcionalne enote, preostale pa so samo v podjetju in tele-koče so nadgradnja informacijskih pisarn in ponujajo poleg informacijske opreme tudi podporo pri izobraževanju ter pomoč pri reševanju problemov.

- Delo na daljavo v novih delovnih okoljih, kjer telekomunikacijska opremljenost omogoča delo na daljavo, to so telecentri so podobni satelitskim pisarnam, vendar s to razliko, da lokacija ni nujno blizu bivalnega okolja; običajno jih vodijo zunanje organizacije in klicni centri ter za svojo uporabo uporabljajo telefone.

- Mobilno in nomadsko delo na daljavo je delo, kjer so zaposleni opremljeni s prenosnimi računalniki, preko katerih komunicirajo s podjetjem.

- Mednarodno delo na daljavo je delo, kjer delavec opravlja delo izven države, kjer je sedež podjetja.

- Delo na daljavo, ki ne potrebuje uporabe informacijskih tehnologij.

- Kombinacije posameznih oblik dela na daljavo, na primer delo na daljavo v kombinaciji z delom v satelitskih pisarnah in pisarnah v soseski.

Delo od doma zaposlenim lahko povzroča dve težavi. Prva je ta ali je koristno upravljanje dela od doma za dvig produktivnosti in donosnosti in druga težava je ta, da se velikokrat zgodi, da se poslabša ravnovesje med poklicnim in zasebnim življenjem. (Bloom, Liang, Roberts \& Ying, 2015, str. 2)

Pametno delo (angl. smart-working) je popolnoma prilagodljiv način dela s sposobnostjo hitrega prilagajanja različnim situacijam. Prožnost dela je večdimenzionalen koncept.

Tradicionalna praksa dela od doma je pod enakimi plačnimi pogoji in nadzorom delodajalca. Delo na daljavo je lahko koristno za produktivnost zaposlenih na njihovo ravnovesje med poklicnim in zasebnim življenjem. Tako da je delo na daljavo le en način delovne prilagodljivosti, ki temelji predvsem na nadomestitvi fizičnega delovnega mesta. Z delom na daljavo organizacije omogočajo svojim zaposlenim zmanjšanje stroškov prevoza na delo, same pa optimizirajo stroške povezane s prevozom. Po drugi strani pa pametno delo vzbuja 
pomisleke glede organizacije produktivnosti zaposlenih in njihovim dobrim počutjem. Mejo med delom in delom od doma lahko povečajo ure nadur, raven stresa zaposlenih in tako se poslabša ravnovesje med poklicnim in zasebnim življenjem. To se lahko tudi zgodi v primeru pametnega dela, ko lahko zaposleni spremeni lokacijo delo brez nadzora delodajalca.

(Angelici \& Profeta, 2020, str. 6)

\section{Metoda}

Predpostavili smo, da obstaja literatura, ki navaja ključne dejavnike za uspešno timsko delo na daljavo. Literatura je na tem področju v zadnjem času močno narasla, rezultati pa kažejo, da delo od doma omogoča zaposlenim delo od kjerkoli in kadarkoli, omogočeno je ravnovesje med družino in službo. Teoretično ozadje predstavlja podlago za empirični del. Priprava preglednega članka je zajemala kvalitativno metodo, metodo kompilacije, s katero smo povzeli že znane rezultate drugih avtorjev, komparativno metodo, kjer smo primerjali prednosti in slabosti timskega dela na daljavo ter deduktivno metodo, s katero smo sklepali na splošno in obratno iz posameznih primerov.

Pregled literature temelji na konceptualni strukturi, ki preveri prednosti in slabosti timskega dela na daljavo, v smislu izboljšanja delovnih procesov. Literatura, ki se nanaša na prikaz prednosti in slabosti je prikazana $\mathrm{v}$ Tabela 3.

Z iskanjem po spodaj navedenih ključnih besedah (glej

Tabela 2) smo izbrali 17 člankov za končen pregled. Zanesljivost in veljavnost smo preverili tako, da smo po desetih dneh ponovno izbrali iste članke in jih analizirali ter dobili enake rezultate. Skupaj smo predelali 30 referenc, od tega 17 člankov. Največ jih je bilo iz leta 2020. Referenca je bila vzeta od leta 1992 do leta 2020. Izločili smo vse, ki niso jasno navajali območja raziskave, ali pa so bili raziskovani na območjih, ki nas ne zanimajo. Iskanje virov je potekalo s pomočjo bibliografskih baz dLib, Google Učenjak, ScienceDirect, Springerlink. Pri tem smo uporabili ključne besede, ki so navedene v 
Tabela 2. V nadaljevanju je prikazan tudi model raziskave Slika 1.

Tabela 2. Iskanje člankov za prednosti, slabosti timskega dela na daljavo (uporabljene baze podatkov, ključne besede pri iskanju)

\section{TIMSKO DELO NA DALJAVO}

Google Učenjak, ScienceDirect, Web of Science, Scopus, dLib.si-digitalna knjižnica Slovenije

\section{Ključne besede:}

teamwork + team + ICT

team management + team + ICT,

working from home + ICT + teamwork.
Ključne besede: timsko delo + tim + IKT, vodenje tima + člani tima + delo na daljavo, delo na daljavo + IKT + timsko delo.

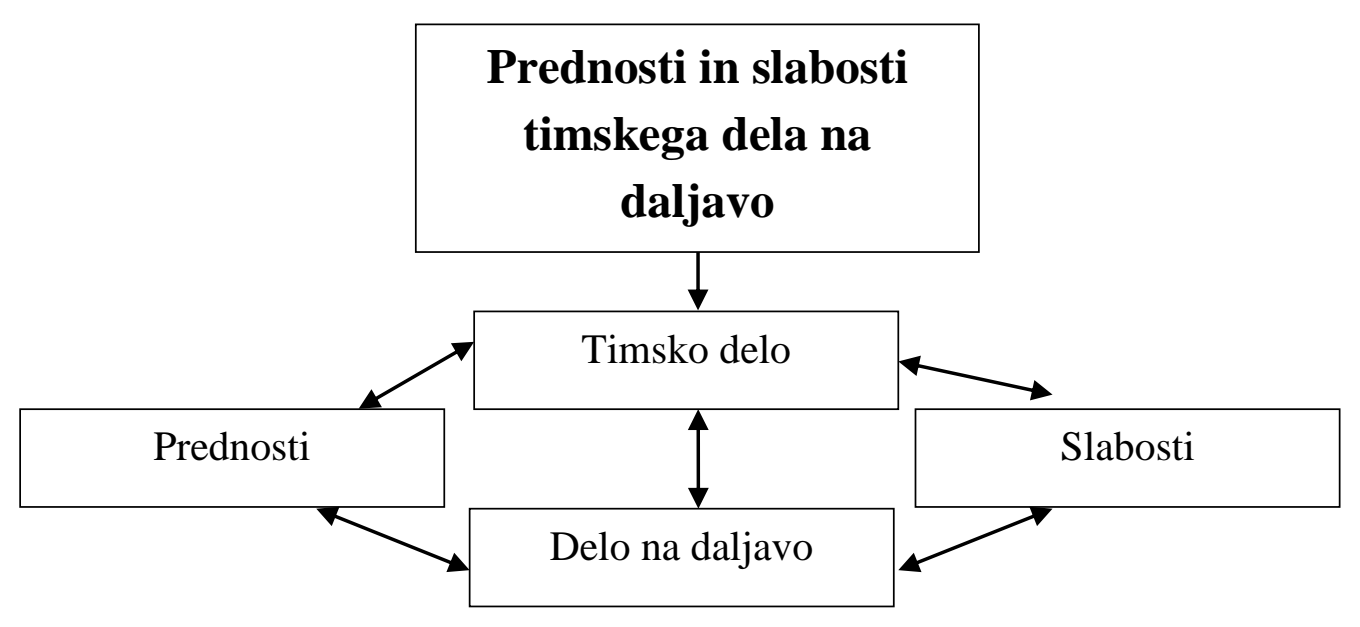


Slika 1. Model raziskave

\section{Rezultati}

\subsection{Rezultati 1}

V Tabela 3 so predstavljene prednosti in slabosti timskega dela na daljavo.

Tabela 3. Vizualni pregled kategorizacije

\begin{tabular}{|c|c|c|}
\hline Avtor & Prednosti & Slabosti \\
\hline $\begin{array}{l}\text { Antonacopoulou, E. P., \& } \\
\text { Georgiadou, A. (2020). }\end{array}$ & $\begin{array}{l}\text { Opravljanje dela od doma } \\
\text { oziroma od kjerkoli. } \\
\text { Opolnomočenje ranljivih } \\
\text { družbenih skupin, varstvo } \\
\text { okolja. Širša ekologija. Boljše } \\
\text { fizično in duševno zdravje, } \\
\text { zadovoljstvo z življenjem, } \\
\text { osebna sreča. Vključenost v } \\
\text { time in skupno delovanje, } \\
\text { zavzetost v karieri }\end{array}$ & $\begin{array}{l}\text { Občutek izolacije od delovnega } \\
\text { okolja, samo socialni stiki in } \\
\text { nič več fizičnih. }\end{array}$ \\
\hline $\begin{array}{ll}\text { »nadaljevanje« } & \text { Goñi-Legaz, S., } \\
& \text { A. (2020). }\end{array}$ & $\begin{array}{l}\text { Ravnovesje med družino in } \\
\text { delom. Ne izgubljanje časa za } \\
\text { vožnjo na delovno mesto. } \\
\text { Zmanjšanje prometnih } \\
\text { zastojev, avtocestnih nesreč, } \\
\text { obremenitev sistema javnega } \\
\text { prevoza. Za podjetja pomeni } \\
\text { delo od doma zmanjšanje } \\
\text { stroškov pisarniških } \\
\text { prostorov, povečanje } \\
\text { produktivnosti zaposlenih. } \\
\text { Večja samostojnost zaposlenih. }\end{array}$ & $\begin{array}{l}\text { Zaposleni so brez nadzora } \\
\text { nadrejenih. Pomanjkanje } \\
\text { dostopa do infrastrukture } \\
\text { informacijske-komunikacijske } \\
\text { tehnologije. Pomanikanie } \\
\text { socialnih interak "se nadaljuje» } \\
\text { družbenih odnosov. Laposıenı } \\
\text { v proizvodnji morajo hoditi še } \\
\text { vedno na delovno mesto. }\end{array}$ \\
\hline $\begin{array}{l}\text { Waizenegger, L., McKenna, B., } \\
\text { Cai, W., \& Bendz, T. (2020). }\end{array}$ & $\begin{array}{l}\text { Možnost ne delanja vsak dan od } \\
\text { doma. Sodelovanje v timu na } \\
\text { daljavo prisili zaposlene v } \\
\text { sodelovanje s sodelavci v } \\
\text { kombinaciji z dodatnimi pritiski } \\
\text { družinskih oseb. Manjše število } \\
\text { konfliktov z družino. Povečanje } \\
\text { števila sestankov, saj so na } \\
\text { daljavo krajši in tako bolj } \\
\text { učinkoviti. }\end{array}$ & $\begin{array}{l}\text { Ne zagotavlja temeljite razlage } \\
\text { določene teme. Občutek } \\
\text { odtujenosti zaradi fizične } \\
\text { razdalje. Spletne } \\
\text { preobremenitve. Spletno } \\
\text { izkoriščanje zaupnih podatkov } \\
\text { (kibernetski kriminalci). } \\
\text { Število brezposelnih narašča } \\
\text { zaradi uvedbe dela na daljavo, } \\
\text { saj se ukinjajo določena delovna } \\
\text { mesta. Hitro prilagajanje } \\
\text { delovnim razmeram. } \\
\text { Prevzemanje več vlog doma }\end{array}$ \\
\hline
\end{tabular}


(delavec, starš, kuhar,..)

Park, Y., Liu, Y., \& Headrick, L. (2020).

Yu, X., Meng, X., Cao, G., \& Jia, Y. (2020).

Breuer, C., Hüffmeier, J., Hibben, F., \& Hertel, G. (2020).

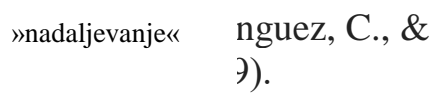

Ladkin, A., Willis, C., Jain, J., Clayton, W., \& Marouda, M. (2016)

Costa, P. L., Passos, A. M., \& Barata, M. C. (2015).

Billon, M., Lera-Lopez, F., \& Marco, R. (2016).
IKT omogoča zaposlenim delo od kjerkoli in kadarkoli, brisanje službenih in družinskih meja. Povečanje učinkovitosti in prilagodljivosti.

Zavzetost za delo.

Timsko zaupanje pozitivno povezano z informacijami, stališči. Izmenjava informacij. Dodelitev odgovornosti.

Timsko delo primerno za ustvarjalne procese. Timska usmeritev prispeva $\mathrm{k}$ večji storilnosti. Timi se oblikujejo, da dosežejo raven uspešnosti.

Komunikacija je temeljna komponenta timskega dela. Timsko delo temelji na sodelovanju.

Lažja povezljivost $s$ sodelavci od doma kjerkoli in kadarkoli. IKT omogoča vzdrževanje odnosov, ki so fizično oddaljeni. Priložnost za družinsko interakcijo.

Uspešnost tima je odvisna od sposobnosti samega tima za trajnost in rast podjetja. Veseli sodelavci. Hitro minevanje časa, saj med delom ne sodelujejo v interakcijah, ki niso povezane $\mathrm{z}$ delom.
Pomanjkanje znanje o uporabi IKT, zato je prisotnega vě stresa.

Več konfliktov med zaposlenim in njegovo družino. Podjetniški neuspeh lahko resno obremenjuje vire, ki so na voljo za delo in potrebe družine, kar lahko povzroči finančni primankljaj.

Ni mogoča razprava fizično. Zmanjševanje nadzora dela. Sporočanje zaupnih informacij preko spleta. Skupna raba zaupnih informacij.

Glavna skrb je timska uspešnost. Nesoglasja zaradi različnih pritiskov, individualne razlike $\mathrm{v}$ ciljih.

$$
\text { »se nadaljuje« }
$$

Izguba delovnih mest. Uporaba IKT ni primerna za vse ljudi določenih starosti -

pomanjkanje znanja o uporabi IKT. Hitrost povezav in razpoložljivost Wi-Fi-ja.

Motenje dela.

\section{Negativna čustva ožijo} pozornost vseh udeležencev, porabijo več časa za analizo informacij.

Pridobiti ustrezno znanje za upravljanje z IKT. 
De Graaff, T., \& Rietveld, P. (2007).

Kang, H. R., Yang, H. D., \& Rowley, C. (2006).

Taskin, L., \& Devos, V. (2005).

Mokhtarian, P. L., \& Salomon, I. (1997).

Bloom, N. (2020).
Večja prilagodljivost zaposlenih, manjša napetost med zaposlenimi. Manjši stroški vožnje, časovni in denarni prihranek. Cenejša sredstva za komunikacijo. Manj onesnaževanja okolja zaradi ne vožnje na delovno mesto.

Dobro počutje zaposlenih. Učinkovitejši zaposleni pri delu s sodelavci zaradi boljše komunikacije. Prilagodljivost pri razporejanju svojega delovnega časa.

Timi prinašajo prednosti podjetju, zaradi združevanja idej, širitev in izboljšanje delovnih procesov, neposredno sodelovanje, opolnomočenje, ki vodi do boljšega sprejemanja odločitev, ustvarjanje in kreiranje rešitev, večja motivacija za delo in posledično manj konfliktov in napačnih informacij. Kognitivne podobnosti članov so bolj pomembne kot pa demografske podobnosti.

Zmanjšanje odsotnosti z dela. Zmanjšanje časa vožnje na delo. Zaposleni imajo večjo avtonomijo in prilagodljivost, kar vodi $\mathrm{k}$ boljšemu uravnoteženju zasebnih in poklicnih nalog.

Delo od doma zmanjšanje število voženj na delovno mesto. Več usmerjenosti k družini, več prostega časa. Manj stresa za vožnjo na delovno mesto.

Delo od doma naj bo 1-3 dni na teden. Vodja sposoben oceniti zaposlene na podlagi rezultatov za njihovo uspešnost.
Znižanje plač zaposlenim, zaradi dela od doma. Ni nujno, da je dobro združiti delovno in družinsko okolje. Sodelavci so podvrženi veliko več motnji pri delu od družine. Delo od doma zmanjša možnosti za napredovanje in s tem pričakovanim zaslužkom.

Stres na sodelavce, prisilni pritiski in nadzor. Timi potrebujejo pogosteje spodbudo, sestavljanje timov in njihovo vodenje je polno negotovosti.
Delo na daljavo še ni zelo razvito in znano vsakomur. Potrebne je več samodiscipline in organizacije. Težja prepoznava odličnih kadrov.

Pomanjkanje socialne interakcije.

Doma primanjkuje tišine, prostora. Težko je biti ustvarjalen od doma, navdihnjen in motiviran. Veliko je izzivov s osamljenostjo. 
Eurofound and the International Delo od doma ni povezana samo Labour Office. (2017)

Lengen, J. C., Kordsmeyer, A. C., Rohwer, E., Harth, V., \& Mache, S. (2020). $\mathrm{z}$ uporabo IKT, temveč tudi z gospodarsko strukturo in kulturo države. Zmanjšanje časa vožnje na delovno mesto, večja avtonomijo delovnega časa, ki vodi do večje produktivnosti pri delu. Boljše ravnovesje med poklicnim in zasebnim življenjem - večja motivacija. Napredek na področju IKT.

Podpora vseh zaposlenih daje prednost podjetju. Hitrejša izmenjava informacij. Povratne informacije in zaupanje so ključnega pomena.
Daljši delovni čas. Njihov dom je tudi njihova pisarna. Dodatno delo od doma ni velikokrat plačano.

Pomanjkanje socialnega druženja.

\section{Razprava}

Pregled literature kaže, da je veliko prednosti in tudi slabosti timskega dela na daljavo, ki so tudi prikazane $\mathrm{v}$

Tabela 4. Antonacopoulou in Georgiadou (2020) sta navedli precej prednosti timskega dela na daljavo. Prva prednost je ta, da se lahko delo opravlja od doma oziroma od kjerkoli in tudi kadarkoli. Poudarili sta opolnomočenje ranljivih skupin, saj z delom od doma dobijo priložnost delati tudi tisti, ki so z različnim namenom podvrženi bivanju doma. Varuje se tudi okolje, ker se ne opravlja prevozov na delo, zaposleni imajo boljše fizično in duševno zdravje, zadovoljni so z življenjem, imajo osebno srečo, ter so vključeni v time in skupno delovanje in so tudi zavzeti v karieri.

Slabosti se pa kažejo predvsem v tem, da ni več fizičnih stikov, temveč so samo socialni, kar zaposlenim daje občutek izolacije od delovnega okolja. Prednosti, ki so bile navedene so tudi 
ravnovesje med družino in delom, ne izgubljanje časa za vožnjo na delovno mesto, posledično zmanjšanje prometnih zastojev, avtocestnih nesreč in manjša obremenitev sistema javnega prevoza. Za podjetje pomeni delo od doma zmanjšanje stroškov pisarniških prostorov in navsezadnje povečanje produktivnosti ter samostojnost zaposlenih.

Veliki minus dela od doma se kaže tudi $\mathrm{v}$ tem, da so zaposleni brez nadzora nadrejenih, pomanjkanje dostopa do infrastrukture informacijske-komunikacijske tehnologije, spletno izkoriščanje zaupnih podatkov (kibernetski kriminalci). Za timsko delo na daljavo ne velja za tiste, ki so zaposleni v proizvodnji, saj ne morejo svojega dela premestiti domov.

Waizenegger, McKenna, Cai in Bendz (2020) pravijo, da se s timskim delom na daljavo poveča število sestankov, saj so na daljavo krajši in tako bolj učinkoviti. Velika slabost je tudi ta, da zaposlena oseba prevzame več vlog doma (delavec, starš, kuhar,...), pomanjkanje znanja o uporabi informacijsko-komunikacijske tehnologije, zato je prisotnega tudi več stresa. Menimo, da delo na daljavo $\mathrm{v}$ timih predstavlja timsko zaupanje, ki je pozitivno povezano $\mathrm{z}$ informacijami, prihaja do večjega izmenjavanja informacij, timsko delo je primerno za ustvarjalne procese, tako da to prispeva $\mathrm{k}$ večji storilnosti in temelji na sodelovanju. Prihaja tudi do različnih nesoglasij zaradi raznolikih pritiskov in tudi zaradi individualnih razlik $\mathrm{v}$ ciljih.

Smo mnenja, da timsko delo na daljavo lahko povzroči veliko izgubo delovnih mest, saj lahko zaposleni opravljajo svoje delo na daljavo, torej od doma oziroma od kjerkoli in kadarkoli. Znižanje plač zaposlenim zaradi dela od doma, dobro je potrebno tudi premisliti ali je dobro združiti delovno in družinsko okolje.

Tabela 4. Prikaz prednosti in slabosti timskega dela na daljavo

\begin{tabular}{ll}
\hline Prednosti & Slabosti \\
\hline - Delo od doma. & - Izolacija. \\
- Opolnomočenje. & - Samo socialni stiki.
\end{tabular}


- Širša ekologija

- Fizično, duševno zdravje.

- Zadovoljstvo zaposlenih.

- Osebna sreča.

- Skupno delovanje.

- Zavzetost.

- Ravnovesje med družino in delom.

- Zmanjšanje prometnih zastojev.

- Povečanje produktivnosti.

- Samostojnost zaposlenih.

- Sodelovanje.

- Manj konfliktov.

- Krajši in učinkoviti sestanki.

- Informacijska-komunikacijska tehnologija.

- Zaupanje.

- Izmenjava informacij.

- Komunikacija.

- Sodelovanje.

- Uspešnost.

- Dobro počutje.

- Motivacija.

- Podpora vseh zaposlenih.
- Brez nadzora.

- Pomanjkanje dostopa do IKT.

- Več konfliktov.

- Finančni primanjkljaj.

- Zmanjševanje nadzora dela.

- Nesoglasja.

- Izguba delovnih mest.

- Motenje dela.

- Negativna čustva.

- Pridobiti znanje o IKT.

- Znižanje plač.

- Manjše možnosti za napredovanje.

- Stres.

- Več nadzora.

- Več samodiscipline in organizacije.

- Daljši delovni čas.

\section{Zaključek}

Skozi integrativni pregled literature smo hoteli potrditi zastavljeno raziskovalno vprašanje. Iskali smo prednosti in slabosti timskega dela na daljavo. $S$ to študijo smo odgovorili na zastavljeno raziskovalno vprašanje in $\mathrm{v}$ nadaljevanju predstavili prednosti in slabosti. Timsko delo na daljavo predstavlja novo obliko dela, ki je že zelo razširjena po celem svetu. Vse več podjetij omogoča zaposlenim delo na daljavo z možnostjo dela na sedežu podjetja. Podjetje oziroma organizacija, ki želi biti uspešna in vodilna, mora biti pripravljena ponuditi zaposlenim nove oblike dela in več timskega dela, saj v timu zaposleni bolj razmišljajo, več predlagajo in nato sledi razprava.

Na timsko delo na daljavo vplivajo različni dejavniki. Eni so pozitivni, drugi negativni. Pri tem velja izpostaviti, da je eden najbolj ključnih pozitivnih dejavnikov ta, da zaposleni opravljajo delo od doma oziroma od kjerkoli ter kadarkoli, omogočen jim je fleksibilen delovni čas, imajo ravnovesje med službo in družino. Slabost se pa kaže v tem, da ni več 
fizičnih stikov, ker so vse interakcije na daljavo, preko spleta. Velik problem je tudi ta, da je ponekod tudi slaba infrastruktura in marsikateri zaposleni nima dobre internetne povezave za nemoteno delo.

Delo na daljavo pomeni, da posameznik opravlja delo v kateremkoli prostoru. Pomembno je, da zna ločiti službeno življenje od privatnega, ter ima organiziran delovni čas, postavljene svoje prioritete in da veliko komunicira še $\mathrm{z}$ ostalimi sodelavci. Vodjem oziroma menedžerjem je priporočeno, da sledijo ukrepom, ki bodo zaposlenim pomagali pri neprekinjenem delovanje oziroma poslovanju, da izkoristijo vsako prednost timskega dela na daljavo in skušajo vsako slabost omiliti, ter bodo zaposlenim dajali občutek motiviranosti in pripadnosti organizaciji.

Kot omejitev velja omeniti, da smo pregled literature oziroma sistematični pregled literature omejili na manjše število virov na omenjeno tematiko, prav tako smo se omejili le na prednosti in slabosti timskega dela na daljavo.

Za širši pregled prednosti in slabosti timskega dela na daljavo bi bilo potrebno preučiti več literature, vključiti več domače literature in narediti primerjavo med prednosti in slabosti timskega dela na daljavo v Sloveniji in tujini.

\section{Reference}

1. Angelici, M., \& Profeta, P. (2020). Smart-working: work flexibility without constraints.

2. Antonacopoulou, E. P., \& Georgiadou, A. (2020). Leading through social distancing: The future of work, corporations and leadership from home. Gender, Work \& Organization.

3. Ashmos, D. P., \& Nathan, M. L. (2002). Team sense-making: A mental model for navigating uncharted territories. Journal of Managerial Issues, 198-217.

4. Billon, M., Lera-Lopez, F., \& Marco, R. (2016). ICT use by households and firms in the EU: links and determinants from a multivariate perspective. Review of World Economics, 152(4), 629-654.

5. Bloom, N. (2020). How working from home works out. Institute for Economic Policy Research (SIEPR). Policy Brief June.

6. Brajša, P. (1996). Sedem skrivnosti uspešnega managementa, Gospodarski vestnik, Ljuljana.

7. Brečko, D. (2003). Kultura timskega dela v slovenskih podjetjih.

8. Breuer, C., Hüffmeier, J., Hibben, F., \& Hertel, G. (2020). Trust in teams: A taxonomy of perceived trustworthiness factors and risk-taking behaviors in face-to-face and virtual teams. human relations, 73(1), 3-34.

9. Costa, P. L., Passos, A. M., \& Barata, M. C. (2015). Multilevel influences of team viability perceptions. Team Performance Management.

10. De Graaff, T., \& Rietveld, P. (2007). Substitution between working at home and out-of-home: The role of ICT and commuting costs. Transportation Research Part A: Policy and Practice, 41(2), 142-160.

11. Eurofound and the International Labour Office. (2017). Working anytime, anywhere: The effects on the world of work. Publications Office of the European Union, Luxembourg, and the International Labour Office, Geneva. 
12. Kang, H. R., Yang, H. D., \& Rowley, C. (2006). Factors in team effectiveness: Cognitive and demographic similarities of software development team members. Human Relations, 59(12), 1681-1710.

13. Kobolt, A. (2012). Timsko delo - nuja in izziv. Vzgoja in izobraževanje, 43(3/4), 5-12.

14. Kovačič, I. (2005). Arhitekturna dimenzija dela na daljavo. Urbani Izziv, 16(1), 93-97.

15. Kralj, J. (2003). Management: temelji managementa, odločanje in ostale naloge managerjev. Visoka šola za management.

16. Ladkin, A., Willis, C., Jain, J., Clayton, W., \& Marouda, M. (2016). Business travellers' connections to home: ICT s supporting work-life balance. New Technology, Work and Employment, 31(3), 255-270.

17. Lahe, M. Kaučič BM. (2006). Timsko delo v očeh študentov zdravstvene nege: Kateri dejavniki vplivajo na njegovo uspešnost. Obzor zdr N. 2006; 40(3): 149-55.

18. Lengen, J. C., Kordsmeyer, A. C., Rohwer, E., Harth, V., \& Mache, S. (2020). Soziale Isolation im Homeoffice im Kontext der COVID-19-Pandemie: Hinweise für die Gestaltung von Homeoffice im Hinblick auf soziale Bedürfnisse. Zentralblatt Fur Arbeitsmedizin, Arbeitsschutz Und Ergonomie, 1.

19. Lipičnik, B. (1998). Ravnanje z ljudmi pri delu. Ljubljana: Gospodarski vestnik.

20. Maddux, R. B. (1992). Oblikovanje teama: vaja v vodenju. Ljubljana: Mladinska knjiga.

21. Mokhtarian, P. L., \& Salomon, I. (1997). Modeling the desire to telecommute: The importance of attitudinal factors in behavioral models. Transportation Research Part A: Policy and Practice, 31(1), 35-50.

22. Moura, I., Dominguez, C., \& Varajão, J. (2019). Information systems project teams: factors for high performance. Team Performance Management: An International Journal.

23. Ollo-López, A., Goñi-Legaz, S., \& Erro-Garcés, A. (2020). Home-based telework: usefulness and facilitators. International Journal of Manpower.

24. Park, Y., Liu, Y., \& Headrick, L. (2020). When work is wanted after hours: Testing weekly stress of information communication technology demands using boundary theory. Journal of Organizational Behavior, 41(6), 518-534.

25. Potokar, F., \& Jereb, E. (2004). Izobraževanje na daljavo. Organizacija, št, 8, 481-484.

26. Skalič A., et. al. (2006). Delo na daljavo: Priročnik za uvajanje novih oblik dela.

27. Taskin, L., \& Devos, V. (2005). Paradoxes from the individualization of human resource management: The case of telework. Journal of Business Ethics, 62(1), 13-24.

28. Trček, F. (2000). Prednosti in nevarnosti teledela - perspektive uvajanja teledela v Sloveniji. Uporabna informatika, 8(2), 8793.

29. Waizenegger, L., McKenna, B., Cai, W., \& Bendz, T. (2020). An affordance perspective of team collaboration and enforced working from home during COVID-19. European Journal of Information Systems, 29(4), 429-442.

30. Yu, X., Meng, X., Cao, G., \& Jia, Y. (2020). Exploring the relationship between entrepreneurial failure and conflict between work and family from the conservation of resources perspective. International Journal of Conflict Management.

Tjaša Gračner je diplomirala na Fakulteti za ekonomijo in informatiko Novo mesto in pridobila naziv diplomirala ekonomistka. Trenutno zaključuje podiplomski študij Menedžment kakovosti na Fakulteti za organizacijske študije Novo mesto. Sodelovala je na projektih, kot so bili »Po kreativni poti do znanja: 
Revija za univerzalno odličnost / Journal of Universal Excellence,

Junij / June 2021, leto / year 10, številka / number 2, str. / pp. 180-194.

Zaposlitvenopodjetniška akademija«, »Daruj krvotvorne matične celice za življenje« in »Medgeneracijsko učenje z robotki in osnovnim programiranjem - ROBO4U«.

\section{Abstract: \\ Advantages and Disadvantages of Teamwork at a Distance}

Research Question (RQ): What are the advantages and disadvantages of teamwork at distance? Purpose: To explore the advantages and disadvantages of teamwork at a distance and to find the reasons for successful or unsuccessful work at a distance.

Method: With the help of an integrative review of the literature or already done research in this field and with the collection of data, we investigated the advantages and disadvantages of teamwork at a distance. To obtain data, we used a qualitative method, a compilation method with which we summarized the results of other authors on this topic, a comparative method for comparing the advantages and disadvantages of teamwork at a distance and a deductive method with which we infer individual cases in general.

Results: The results of all surveys do not differ significantly, as the advantages and disadvantages of teamwork at a distance of employees depend on similar parameters: working hours, age, position in the company, infrastructure, possibilities of combining work and family.

Organization: The impact on the organization is strong as it allows the organization to achieve better employee productivity, they can have a flexible work schedule, the organization does not have high costs with physical offices and with the cost of transporting employees to work. It is also important that organizations are aware of the importance of the benefits of teleworking and encourage productivity, innovation, and that the leader rewards them accordingly.

Society: Theoretical part starting points guide society to the use of telework and teamwork, as more people together can do much more, improve, innovate. Teleworking has a positive effect on employees.

Originality: The originality of the research is reflected in the breakdown of the advantages and disadvantages of teamwork at a distance. The topic focused on highlighting the benefits of teamwork at a distance, which greatly contributes to the development of the company.

Limitations/Future Research: To get a broader view of the advantages and disadvantages of teamwork at a distance, more literature would need to be examined. For further research, we should explore the various costs that threaten companies in terms of introducing telework and ways to help companies and employees work remotely in a team.

Keywords: team, team work, team management, team communication, team members, teleworking, information and communication technology.

Copyright (c) Tjaša GRAČNER



Creative Commons License

This work is licensed under a Creative Commons Attribution-ShareAlike 4.0 International License. 